\title{
Holocene Core Logs and Site Methods for Modern Reef and Head-Coral Cores: Dry Tortugas National Park, Florida
}

By Todd D. Hickey, Christopher D. Reich, Kristine L. Delong, Richard Z. Poore, and John C. Brock

Open-File Report 2012-1095

U.S. Department of the Interior

U.S. Geological Survey 


\section{U.S. Department of the Interior \\ Ken Salazar, Secretary}

\section{U.S. Geological Survey \\ Suzette M. Kimball, Acting Director}

U.S. Geological Survey, Reston, Virginia 2013

For product and ordering information:

World Wide Web: http://www.usgs.gov/pubprod

Telephone: 1-888-ASK-USGS

For more information on the USGS-the Federal source for science about the Earth,

its natural and living resources, natural hazards, and the environment:

World Wide Web: http://www.usgs.gov

Telephone: 1-888-ASK-USGS

Suggested citation:

Hickey, T.D., Reich, C.D., Delong, K.L., Poore, R.Z., and Brock, J.C., 2013, Holocene core logs and site methods for modern reef and head-coral cores - Dry Tortugas National Park, Florida: U.S. Geological Survey Open-File Report 2012-1095, $27 \mathrm{p}$.

Any use of trade, product, or firm names is for descriptive purposes only and does not imply endorsement by the U.S. Government.

Although this report is in the public domain, permission must be secured from the individual copyright owners to reproduce any copyrighted material contained within this report. 


\section{Contents}

Introduction

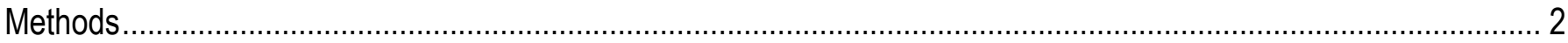

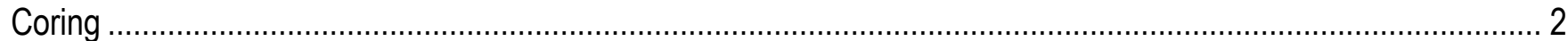

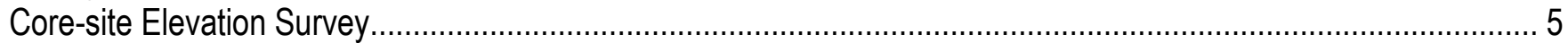

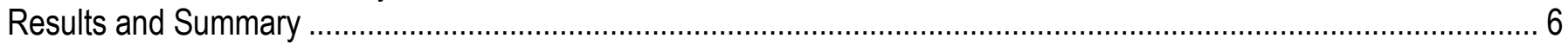

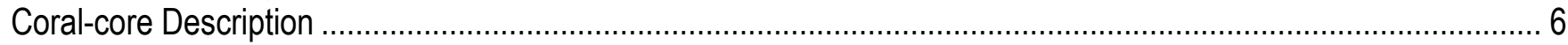

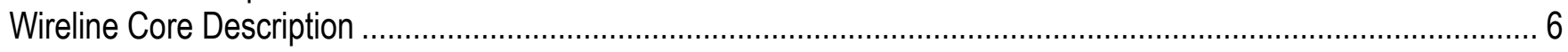

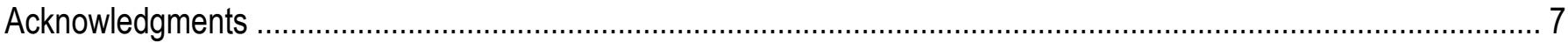

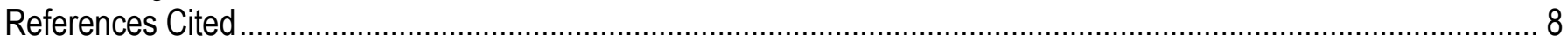

Appendix 1. Photographs of cored corals, Dry Tortugas National Park, Florida .................................................... 9

Appendix 2. Lithologic logs and core photographs, Dry Tortugas National Park, Florida .......................................19

\section{Figures}

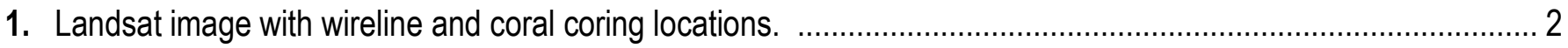

2. Underwater photograph of tripod and wireline coring system. ............................................................. 4

3. Diver operating the hand-held drill while coring a Montastraea faveolata coral at site C2. ............................... 5

\section{Tables}

1. Holocene core information from Dry Tortugas National Park, Florida..................................................... 3

2. Coral core information from Dry Tortugas National Park, Florida. ........................................................... 7 


\section{Conversion Factors}

Inch/Pound to SI

\begin{tabular}{lcl}
\hline \multicolumn{1}{c}{ Multiply } & \multicolumn{1}{c}{ By } & \multicolumn{1}{c}{ To obtain } \\
\hline inch (in.) & Length & \\
inch (in.) & 2.54 & centimeter (cm) \\
foot (ft) & 25.4 & millimeter (mm) \\
mile (mi) & 0.3048 & meter (m) \\
mile, nautical (nmi) & 1.609 & kilometer $(\mathrm{km})$ \\
\hline & 1.852 & kilometer $(\mathrm{km})$ \\
\hline acre & Area & \\
acre & 0.4047 & hectare (ha) \\
square mile $\left(\mathrm{mi}^{2}\right)$ & 0.004047 & square kilometer $\left(\mathrm{km}^{2}\right)$ \\
square mile $\left(\mathrm{mi}^{2}\right)$ & 259.0 & hectare (ha) \\
\hline
\end{tabular}

Temperature in degrees Celsius $\left({ }^{\circ} \mathrm{C}\right)$ may be converted to degrees Fahrenheit $\left({ }^{\circ} \mathrm{F}\right)$ as follows: ${ }^{\circ} \mathrm{F}=\left(1.8 \times{ }^{\circ} \mathrm{C}\right)+32$

Temperature in degrees Fahrenheit $\left({ }^{\circ} \mathrm{F}\right)$ may be converted to degrees Celsius $\left({ }^{\circ} \mathrm{C}\right)$ as follows: ${ }^{\circ} \mathrm{C}=\left({ }^{\circ} \mathrm{F}-32\right) / 1.8$

Horizontal coordinate information is referenced to North American Datum of 1983 (NAVD 83). 


\title{
Holocene Core Logs and Site Methods for Modern Reef and Head-Coral Cores: Dry Tortugas National Park, Florida
}

\author{
By Todd D. Hickey, Christopher D. Reich, Kristine L. Delong, Richard Z. Poore, and John C. Brock
}

\section{Introduction}

The Dry Tortugas are a series of islands, banks, and channels on a carbonate platform off the west end of the Florida Keys. Antecedent topography of the Dry Tortugas reflects carbonate accumulations of the last interglacial (marine isotope substage 5e, $\sim 125,000$ years ago, ka) when sea level was $\sim 6$ to 7 meters $(\mathrm{m})$ higher than present (Schrag and others, 2002). The substage 5e surface was subsequently lithified and modified during subaerial exposure associated with lower sea level from $\sim 120 \mathrm{ka}$ to $8 \mathrm{ka}$. The lithified late Pleistocene carbonates are known as the Key Largo Limestone, a coral reef (Hoffmeister and Multer, 1964; Multer and others, 2002), and the Miami Limestone, a tidalbar oolite (Sanford, 1909; Hoffmeister, 1974). The Holocene and modern sediments and reefs of the Dry Tortugas then accreted during the rise of sea level associated with the end of the last glacial and the start of the current interglacial (marine isotope Stage 1).

With the exception of a half dozen or so islands, the Dry Tortugas region has been submerged for approximately 8,000 years, allowing conditions suitable for coral reef formation once again. The Holocene reef accumulation varies in thickness due to the antecedent topography. The reefs are composed of massive head corals such as species of Montastraea, Siderastrea, and Diploria (Swart and others, 1996; Cohen and McConnaughey, 2003) and rest atop the Pleistocene Key Largo Limestone high (Shinn and others, 1977). The coral reefs within the Dry Tortugas represent a windward reef margin relative to dominant wind and wave energies (Hine and Mullins, 1983; Mallinson and others, 1997; Mallinson and others, 2003). 


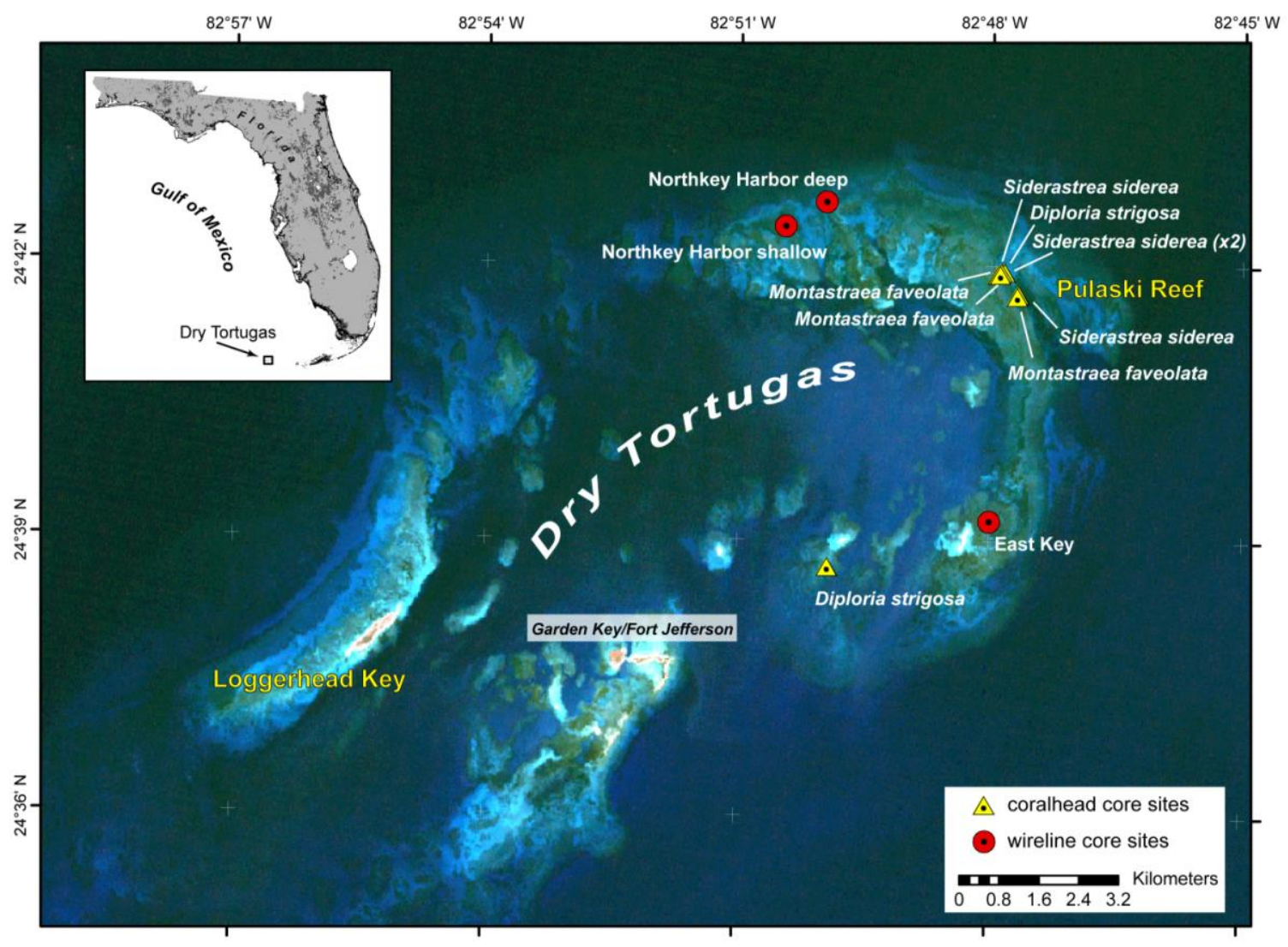

Figure 1. Landsat image with wireline and coral coring locations. Inset shows Dry Tortugas National Park study site in Florida.

Dry Tortugas National Park, established in 1992, occupies an area of approximately 259 square kilometers $\left(\mathrm{km}^{2}\right)$ and is located 110 kilometers $(\mathrm{km})$ west of Key West, Fla. The isolation and relatively low anthropogenic impacts make the Dry Tortugas an ideal area from which to collect Holocene and modern coral cores to be used as a proxy for multidecadal paleoclimate reconstructions. This report summarizes the 2008 Dry Tortugas core-collection project and provides information on the methods used.

\section{Methods}

\section{Coring}

Northkey Harbor and East Key were core drilled with the U.S. Geological Survey (USGS) portable hydraulic drill to recover lithologic samples spanning the Holocene back into the late Pleistocene. Reich and others (2009) provide a complete description of the coring method. Three Holocene cores were recovered one from East Key and two from Northkey Harbor (fig. 1, table 1). The hydraulic drill was powered by an 18-horsepower (hp) Briggs and Stratton engine. Another 18-hp Briggs and Stratton engine was used to hydraulically power a water pump that forced water down the 
annulus of the drill stem to lubricate and clean the predominantly carbonate cuttings from the drill-stem annulus. The core barrel was a Longyear NQ2 wireline system (fig. 2).

Table 1. Holocene core information from Dry Tortugas National Park, Florida.

\begin{tabular}{|c|c|c|c|c|c|c|}
\hline $\begin{array}{c}\text { Date } \\
\text { Collected }\end{array}$ & $\begin{array}{c}\text { Site } \\
\text { Name }\end{array}$ & $\begin{array}{c}\text { Reef } \\
\text { Name }\end{array}$ & $\begin{array}{c}\text { Latitude } \\
\left({ }^{\circ} \mathbf{N}\right)\end{array}$ & $\begin{array}{c}\text { Longitude } \\
\left({ }^{\circ} \mathbf{W}\right)\end{array}$ & $\begin{array}{c}\text { Water Depth } \\
(\text { meters })\end{array}$ & $\begin{array}{c}\text { Core Length } \\
(\text { meters })\end{array}$ \\
\hline & & & & & & \\
\hline $8 / 10 / 08$ & $\begin{array}{c}\text { EK } \\
\text { shallow }\end{array}$ & East Key & 24.65372 & -82.79980 & 5.3 & 18.3 \\
\hline $8 / 11 / 08$ & $\begin{array}{c}\text { NKH } \\
\text { shallow }\end{array}$ & Northkey Harbor & 24.70702 & -82.84075 & 3.9 & 12.2 \\
\hline $8 / 12 / 08$ & $\begin{array}{c}\text { NKH } \\
\text { deep }\end{array}$ & Northkey Harbor & 24.71143 & -82.83265 & 6.7 & 10.7 \\
\hline
\end{tabular}

This system retrieved a 2-inch (in.)-diameter rock core and left a 3-in. open hole when the drilling was complete. Each piece of drill pipe was 5 feet (ft) long. Therefore, at each 5 -ft depth interval, the drilling stopped and the inner barrel was retrieved. The drill head was removed, and the overshot (an inner barrel retrieval device) attached with line was sent down inside the drill string to engage and lock on the inner barrel. The inner barrel assembly consisted of two stainless-steel split barrels that were held together by a core catcher on the bottom end and a device referred to as the spearhead, which forms the contact at the upper end. Next, the overshot was connected to the spearhead, and the inner barrel was raised out of the drill stem. To keep the operation running smoothly, two inner barrels were used so the one removed could be replaced right away. Once the overshot and the full inner barrel were removed from inside the drill stem, the second inner barrel was immediately attached to the overshot and placed within the drill stem. The empty inner barrel was then lowered to the base of the drill stem, and a device called the messenger was sent down the line to disengage the overshot from the spearhead. After pulling the overshot out of the drill stem, another 5-ft section of drill pipe was added, and the drill head was screwed back onto the drill string. This process was repeated until the desired depth of penetration was acquired, which, in this case, was indicated by recovery of the Pleistocene Key Largo Limestone at $\sim 35$ $\mathrm{ft}$ below the core top at the ground surface. 


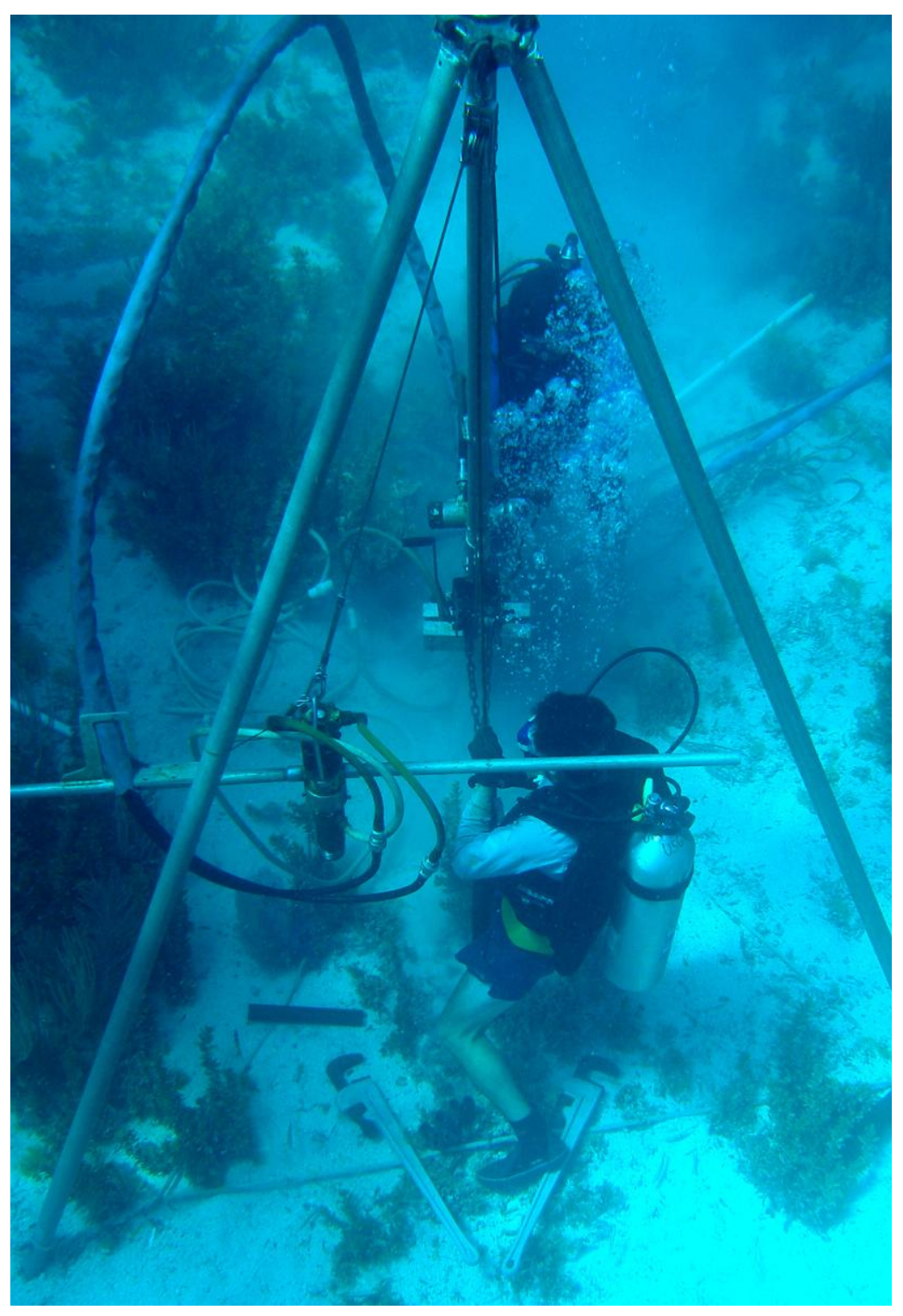

Figure 2. Underwater photograph of tripod and wireline coring system.

Coral coring methods were less labor intensive. The drill head was a DL07652 Stanley hydraulic drill with a 4-in.-diameter core barrel 24 in. in length attached to the drill (fig. 3). A small hole was made in the coral surface with a $1 / 4$-in. starting bit to prevent the 4 -in. drill bit from "walking" across the top of the head coral. To collect full coral cores, extension pieces were added after the coral core was recovered from the diamond-studded core barrel. This process was repeated until the base of the coral was penetrated. 


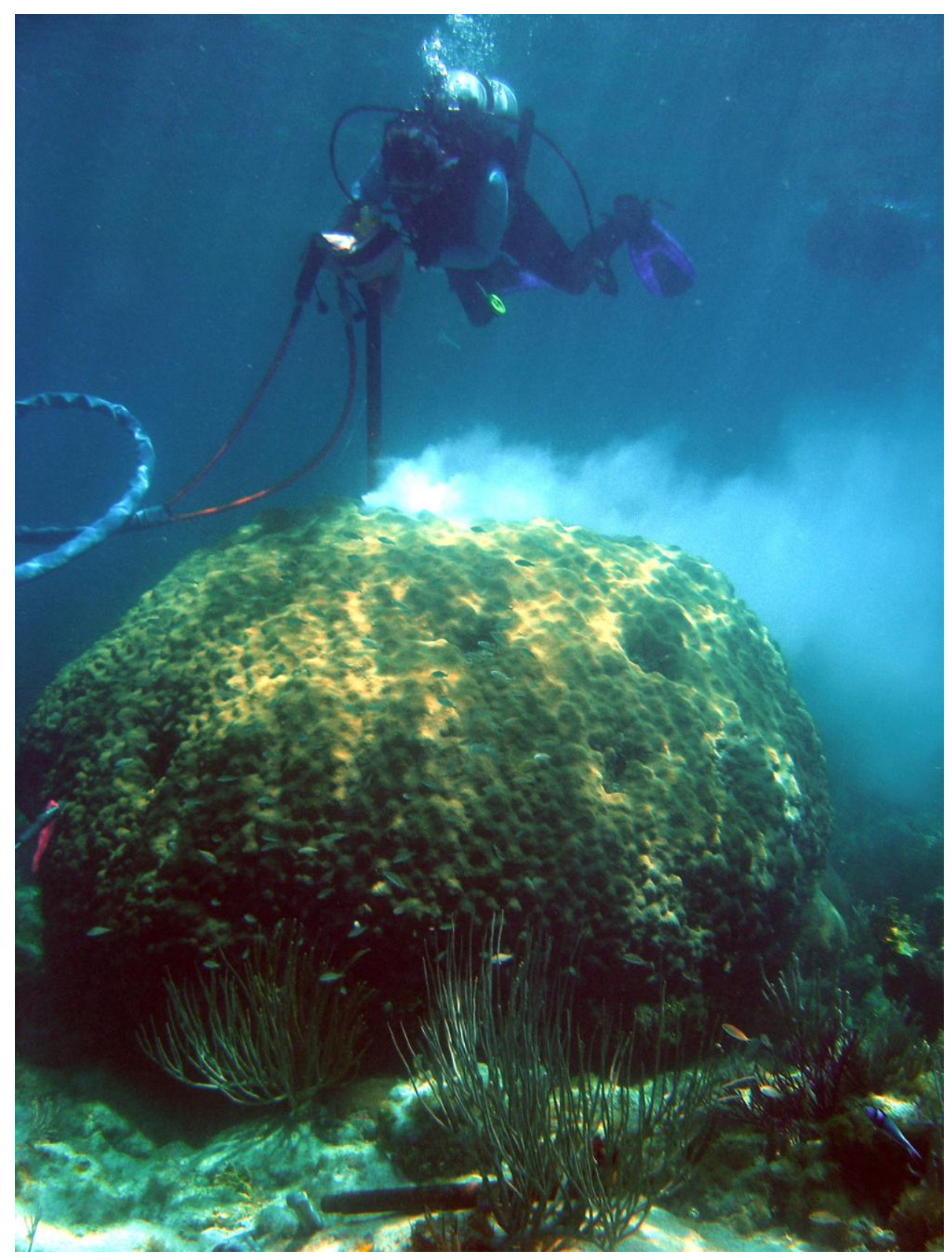

Figure 3. Diver operating the hand-held drill while coring a Montastraea faveolata coral at site C2.

\section{Core-site Elevation Survey}

Proper elevation control for each Holocene core was necessary for correlating the recovered cores. Elevations were acquired using a kinematic global positioning system (GPS) system at the wireline coring sites. Ashtech high-precision, dual-frequency GPS receivers coupled with Thales choke- 
ring antennas were used for this survey. Seco GPS poles were used to mount the antenna to the drilling tripod and were leveled using a hand level. A base station was set up on top of the Civil War-era Fort Jefferson over a previously established benchmark. Minimal time (30 minutes) was needed to obtain the core-site elevation (sessions) due to the $<15-\mathrm{km}$ distance between coring and base-station locations. Sessions were processed using the NovAtel GrafNet program.

\section{Results and Summary}

\section{Coral-core Description}

Three different coral genera were selected for coring: Montastraea, Siderastrea, and Diploria. Coral cores were recovered near Middle Key and on Pulaski Reef (fig. 1). Photographs of the cored heads are presented in appendix 1. Nine coral cores were recovered (table 2).

\section{Wireline Core Description}

One objective of this study was to recover complete Holocene cores in the Dry Tortugas to facilitate and expand paleoclimate studies within the USGS. Previous USGS drilling expeditions in the Dry Tortugas (1976, 1997, and 2004) provided valuable information about the depth of penetration for complete recovery of the Holocene section. Three long cores were attempted in this study with varying degrees of success. Core logs were generated using LogPlot99 and Adobe Illustrator software. The logs (accompanied with Holocene and Pleistocene core photographs) are shown in appendix 2. The core logs include depth of recovery, sedimentary structure, lithologic description, core-recovery percentages, location coordinates, site elevation, and other pertinent observations. 
Table 2. Coral core information from Dry Tortugas National Park, Florida.

\begin{tabular}{|c|c|c|c|c|c|c|c|c|}
\hline $\begin{array}{c}\text { Date } \\
\text { Collected }\end{array}$ & $\begin{array}{c}\text { Site } \\
\text { Name }\end{array}$ & $\begin{array}{c}\text { Photo } \\
\text { ID }\end{array}$ & $\begin{array}{l}\text { Reef } \\
\text { Name }\end{array}$ & $\begin{array}{l}\text { Coral } \\
\text { Species }\end{array}$ & $\begin{array}{c}\text { Latitude } \\
\qquad\left(\mathbf{N}^{\circ}\right)\end{array}$ & $\begin{array}{c}\text { Longitude } \\
\qquad\left(\mathbf{W}^{\circ}\right)\end{array}$ & $\begin{array}{l}\text { Water } \\
\text { Depth } \\
\text { (meters) }\end{array}$ & $\begin{array}{l}\text { Core Length } \\
\text { (centimeters) }\end{array}$ \\
\hline $8 / 6 / 08$ & 08MK-A1 & A1 & $\begin{array}{c}\text { Middle } \\
\text { Key }\end{array}$ & $\begin{array}{l}\text { Diploria } \\
\text { strigosa }\end{array}$ & 24.64530 & -82.83205 & 3.4 & 23 \\
\hline $8 / 6 / 08$ & 08PS-A1 & A2 & Pulaski & $\begin{array}{c}\text { Siderastrea } \\
\text { siderea }\end{array}$ & 24.69883 & -82.79745 & 4.3 & 113 \\
\hline $8 / 6 / 08$ & 08PS-A2 & $\mathrm{A} 3$ & Pulaski & $\begin{array}{c}\text { Siderastrea } \\
\text { siderea }\end{array}$ & 24.69883 & -82.79745 & 4.3 & 83 \\
\hline $8 / 7 / 08$ & 08PS-B1 & B1 & Pulaski & $\begin{array}{c}\text { Siderastrea } \\
\text { siderea }\end{array}$ & 24.69887 & -82.79810 & 3.4 & 46 \\
\hline $8 / 7 / 08$ & 08PS-C1 & B2 & Pulaski & $\begin{array}{c}\text { Diploria } \\
\text { strigosa }\end{array}$ & 24.69887 & -82.79810 & 3.4 & 60 \\
\hline $8 / 7 / 08$ & 08PS-B3 & B3 & Pulaski & $\begin{array}{c}\text { Montastraea } \\
\text { faveolata }\end{array}$ & 24.69857 & -82.79862 & 3.4 & 142 \\
\hline $8 / 7 / 08$ & 08PS-B4 & B4 & Pulaski & $\begin{array}{l}\text { Montastraea } \\
\text { faveolata }\end{array}$ & 24.69847 & -82.79835 & 3.4 & 110 \\
\hline $8 / 8 / 08$ & 08PS-F1 & $\mathrm{C} 1$ & Pulaski & $\begin{array}{c}\text { Siderastrea } \\
\text { siderea }\end{array}$ & 24.69495 & -82.79465 & 3.7 & 64 \\
\hline $8 / 8 / 08$ & 08PS-C2 & $\mathrm{C} 2$ & Pulaski & $\begin{array}{c}\text { Montastraea } \\
\text { faveolata }\end{array}$ & 24.69460 & -82.79490 & 3.7 & 156 \\
\hline
\end{tabular}

Previous work has indicated the Holocene accretion is approximately $15 \mathrm{~m}$ thick regionally (Hoffmeister and Multer, 1964; Multer and others, 2002). This study is in agreement. Evidence is observed in the shallow Northkey Harbor site where a subaerial unconformity is found $35 \mathrm{ft}$ below the seafloor. The three Holocene cores provided similarities and differences with respect to lithologies down core. Carbonate muds were prevalent near East Key and were reduced at the shallow Northkey Harbor site. All three sites included boulder corals as the main reef builders throughout the region, with little or no presence of branching or finger corals. The cores show that reefs of the Dry Tortugas have geologically evolved through predominantly boulder/massive head-coral accretion and not as much due to branching or finger corals. Other lithologic matrices observed include mudstones, packstones, and grainstones, but are few and far between in relation to the head-coral assemblages. Some of the common biogenic participants observed in all the cores include coralline algae, calcareous worm tubes, bioeroders, and bivalves.

\section{Acknowledgments}

We thank P.J. Walker of Everglades National Park for permission and access to Dry Tortugas National Park. Captains Clay Douglass, Janie Douglass, and John Spade of Dry Tortugas National Park provided logistical support above and beyond that necessary to help make the coring a success, and for that, we are most appreciative. Thanks are extended to Jordan Sanford and B.J. Reynolds of the USGS and Michèle LaVigne of Rutgers University for assistance in the collection of the cores. The USGS Coastal and Marine Program funded the project. 


\section{References Cited}

Cohen A, and McConnaughey, T.A., 2003, Geochemical perspectives on coral mineralization: Reviews in Mineralogical and Geochemistry, v. 54, p. 151-187.

Dunham, R.J., 1962, Classification of carbonate rocks according to depositional texture, in Ham, W.E., ed., Classification of carbonate rocks: American Association of Petroleum Geologists Memoir, p. 108-121.

Hine, A.C., and Mullins, H.T., 1983, Modern carbonate shelf-slope breaks, in Stanley, D.J., and Moore, G.T., eds., The shelfbreak- Critical interface on continental margins: Society of Economic Paleotologists and Mineralogists Special Publication 33, p. 169-188.

Hoffmeister, J.E., 1974, Land from the sea: The Geologic story of south Florida: University of Miami Press, 143 p.

Hoffmeister, J.E., and Multer, H.G., 1964, Growth rate estimates of a Pleistocene reef of Florida: Geologic Society of American Bulletin, v. 75, no. 4, p. 353-357.

Mallinson, D., Hine, A.C., Hallock, P., Locker, S., Shinn, E.A., Naar, D., Donahue, B., and Weaver, D., 2003, Development of small carbonate banks on the south Florida platform margin- Response to sea level and climate change: Marine Geology, v. 199, p. 45-63.

Mallinson, D., Locker, S., Hafen, M., Naar, D., Hine, A., Lavoie, D., and Schock, S., 1997, A highresolution geological and geophysical investigation of the Dry Tortugas carbonate depositional environment: Geo-Marine Letters, v. 17, p. 237-245.

Multer, H.G., Gischler, E., Lundberg, J., Simmons, K., and Shinn, E.A., 2002, Key Largo Limestone revisited: Pleistocene shelf-edge facies, Florida Keys, USA: Facies, v. 46, p. 229-272.

Reich, C.D., Hickey, T.D., Delong, K.L., Poore, R.Z., and Brock, J.C., 2009, Holocene core logs and site statistics for modern patch-reef cores- Biscayne National Park, Florida: U.S. Geological Survey Open-File Report 2009-1246, 69 p., available at http://pubs.usgs.gov/of/2009/1246/.

Sanford, S., 1909, The topography and geology of southern Florida: Florida Geologic Survey annual report, Florida Geological Survey, Tallahassee, Fla, p. 175-231.

Schrag, D.P., Adkins, J.F., McIntyre, K., Alexander, J.L., Hodell, D.A., Charles, C.D., and McManus, J., 2002, The oxygen isotope of seawater during the last glacial maximum: Quaternary Science Reviews, v. 21, no. 1-3, p. 331-342.

Shinn, E.A., 2001, Coral reefs and shoreline dipsticks: American Association of Petroleum Geologists Studies in Geology, v. 47, p. 251-264.

Shinn, E.A., Hudson, J.H., Halley, R.B., and Lidz, B.H., 1977, Topographic control and accumulation rate of some Holocene coral reefs, South Florida and Dry Tortugas: Proceedings, Third International Coral Reef Symposium, v. 2, Geology, Miami, Fla., p. 1-7.

Swart, P.K., Dodge, R.E., and Hudson, H.J., 1996, A 240-year stable oxygen and carbon isotope record in a coral from south Florida-Implications for the prediction of precipitation in southern Florida: PALAIOS, v. 11, no. 4, p. 362-375. 
Appendix 1. Photographs of cored corals, Dry Tortugas National Park, Florida 


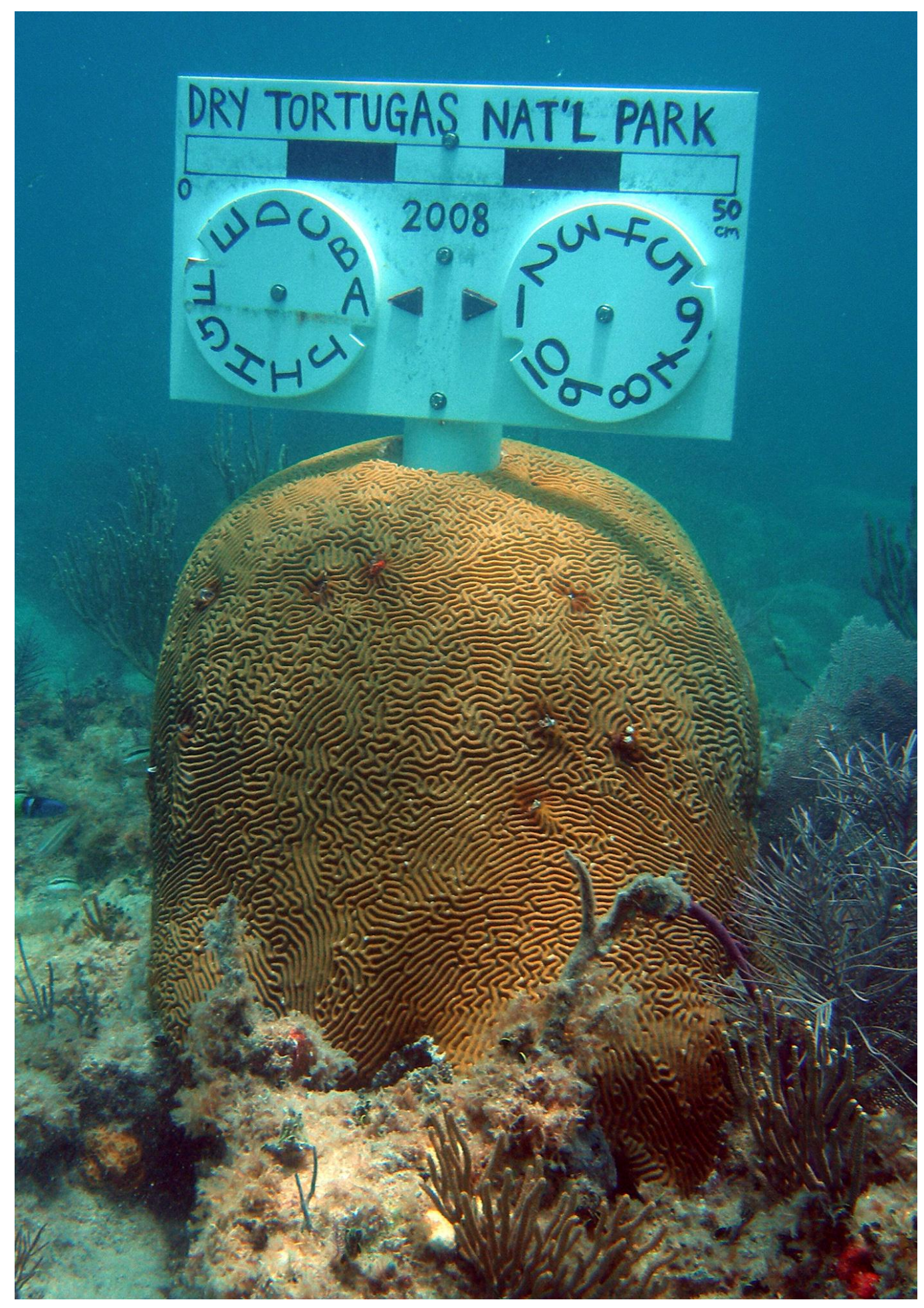

Site 08MK-A1, Diploria strigosa. 


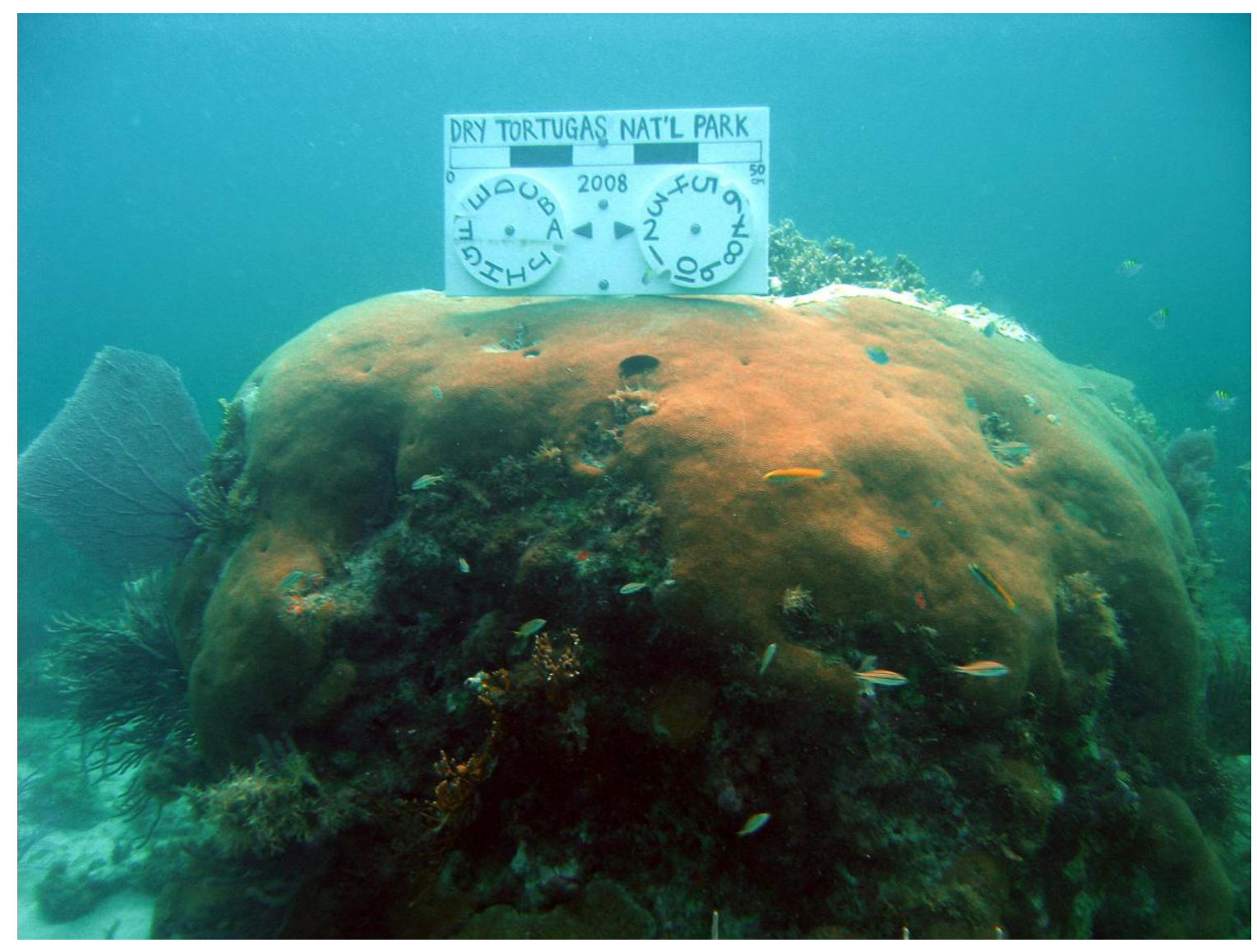

Site 08PS-A1, Siderastrea siderea. 


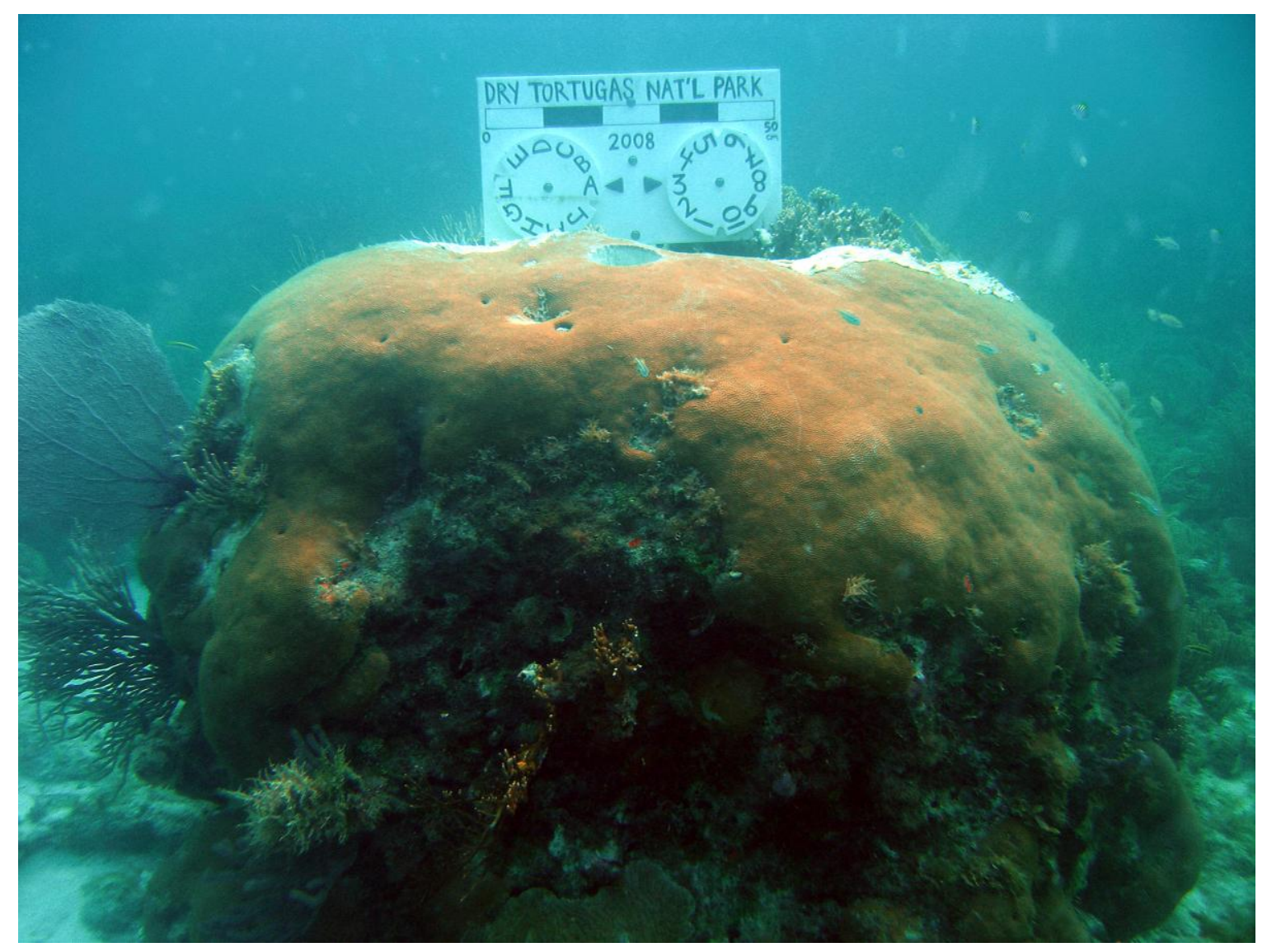

Site 08PS-A2, Siderastrea siderea. 


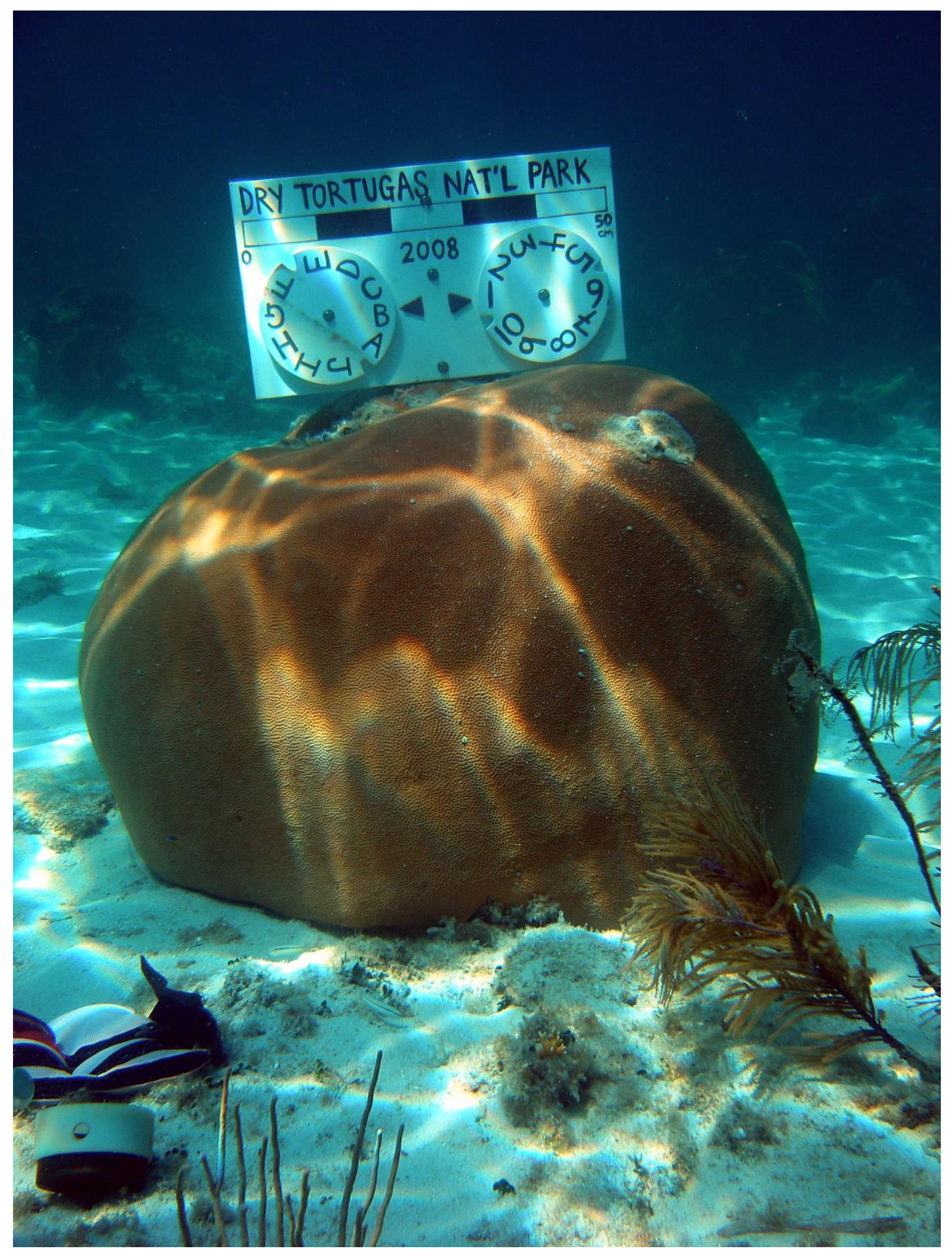

Site 08PS-B1, Siderastrea siderea. 


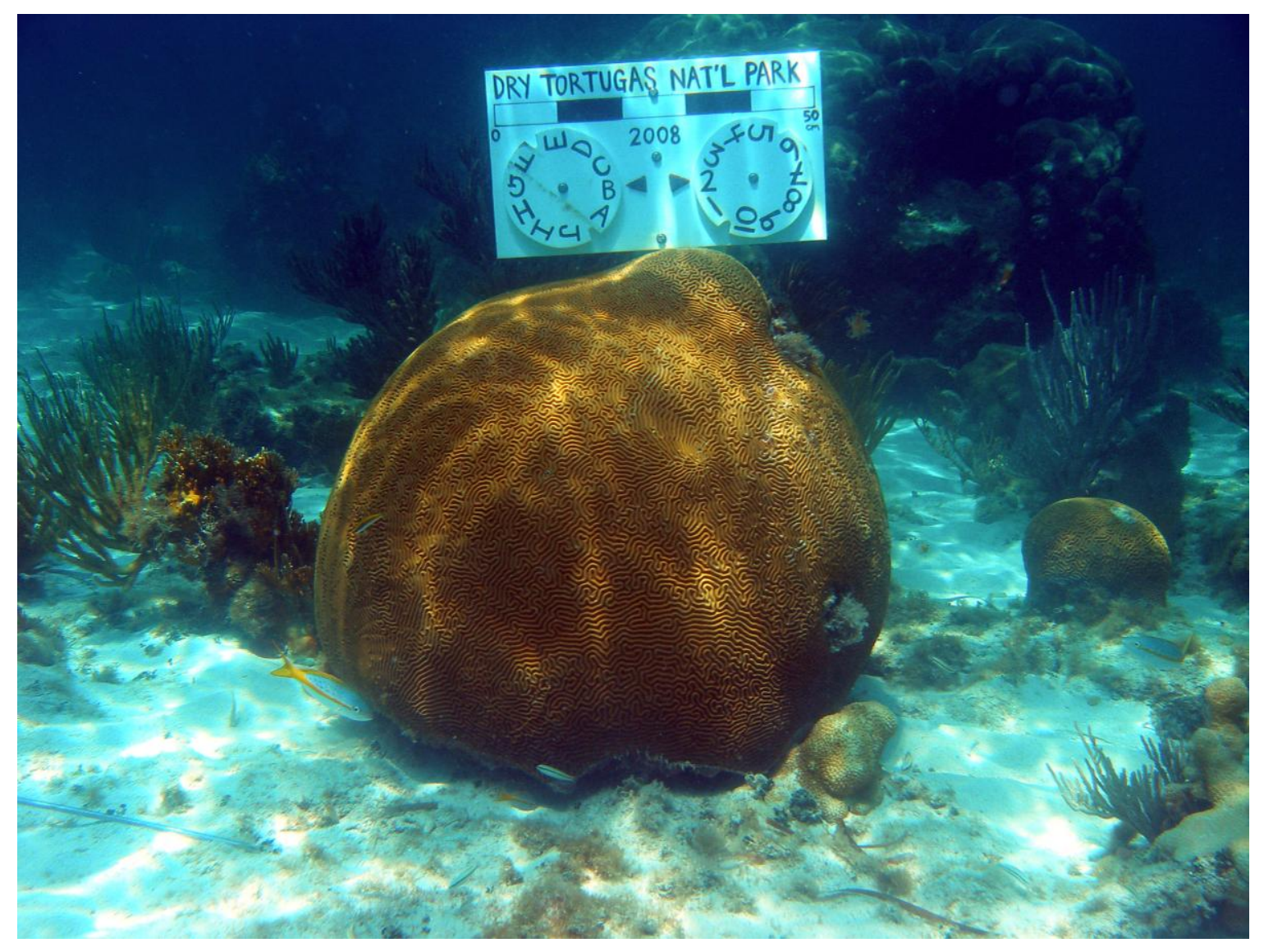

Site 08PS-C1, Diploria strigosa. 


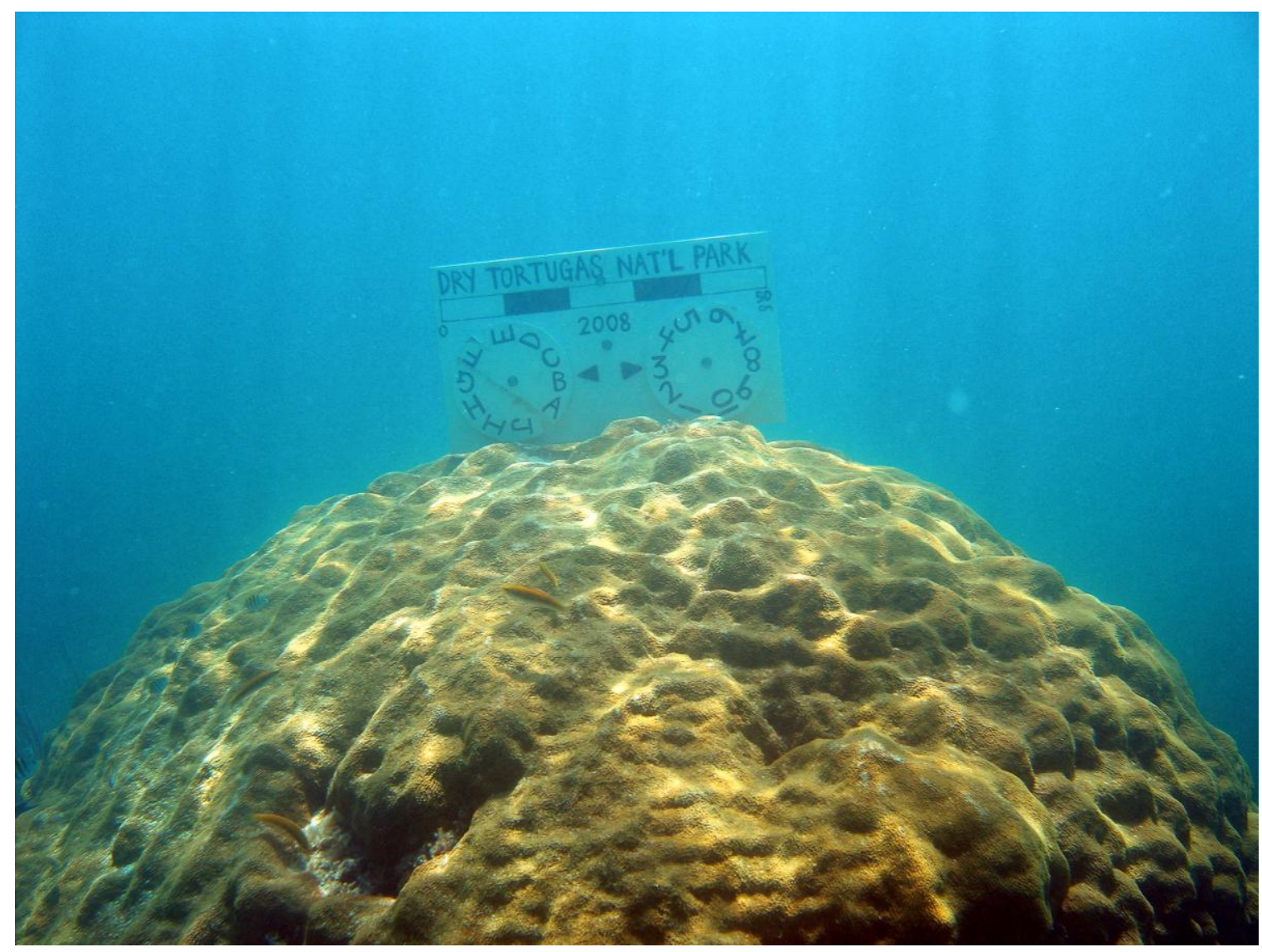

Site 08PS-B3, Montastraea faveolata. 


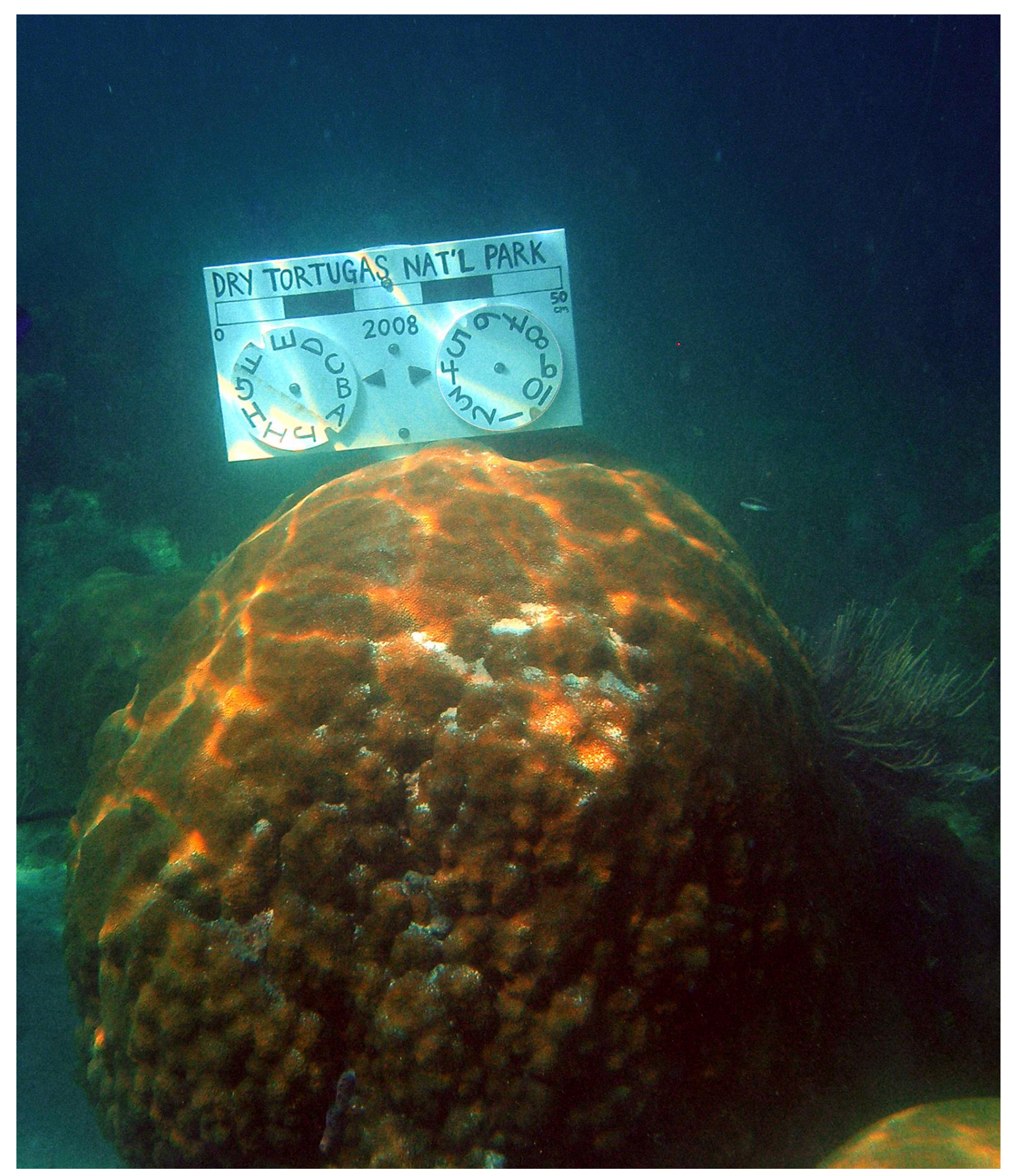

Site 08PS-B4, Montastraea faveolata. 


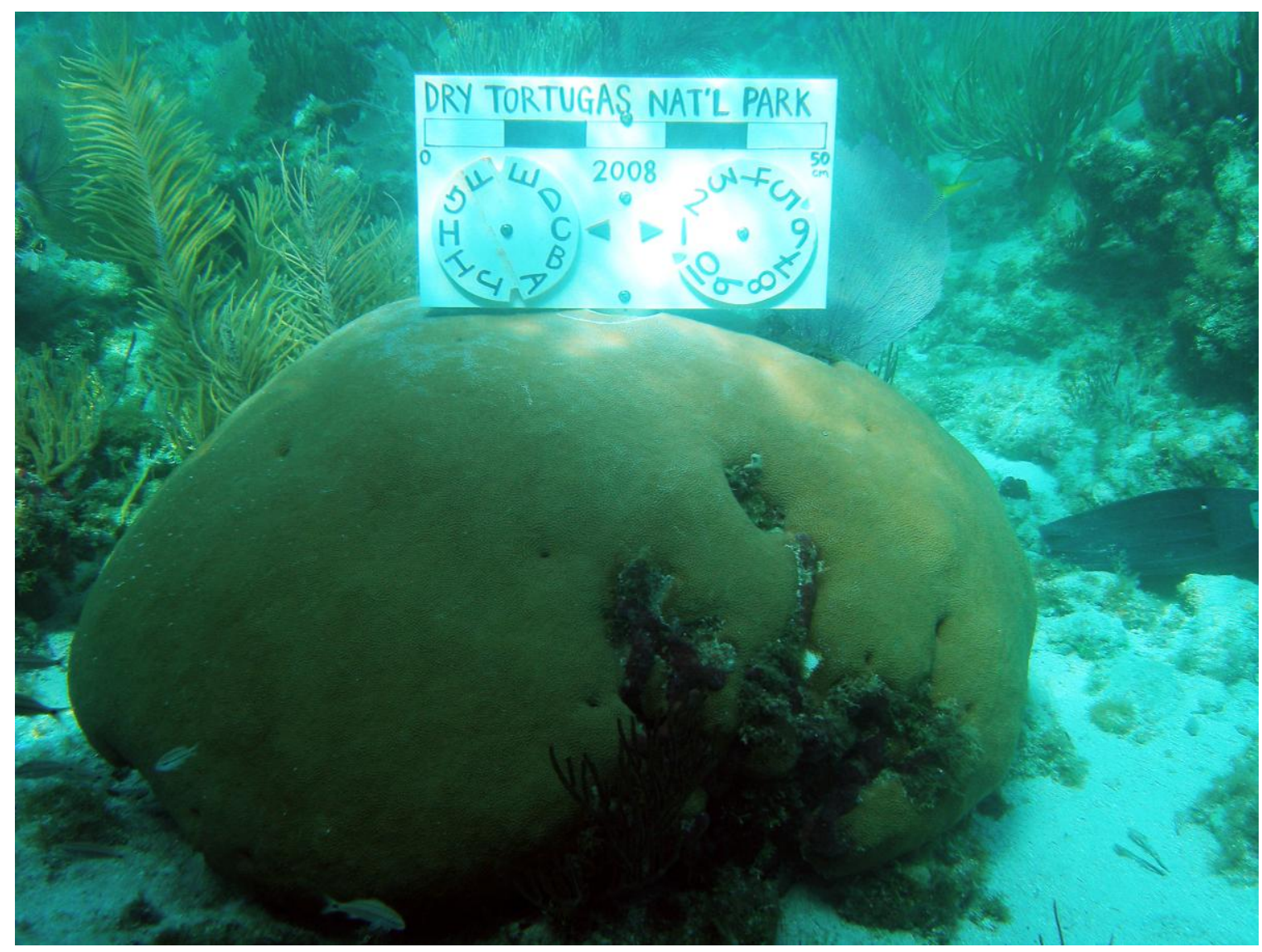

Site 08PS-F1, Siderastrea siderea. 


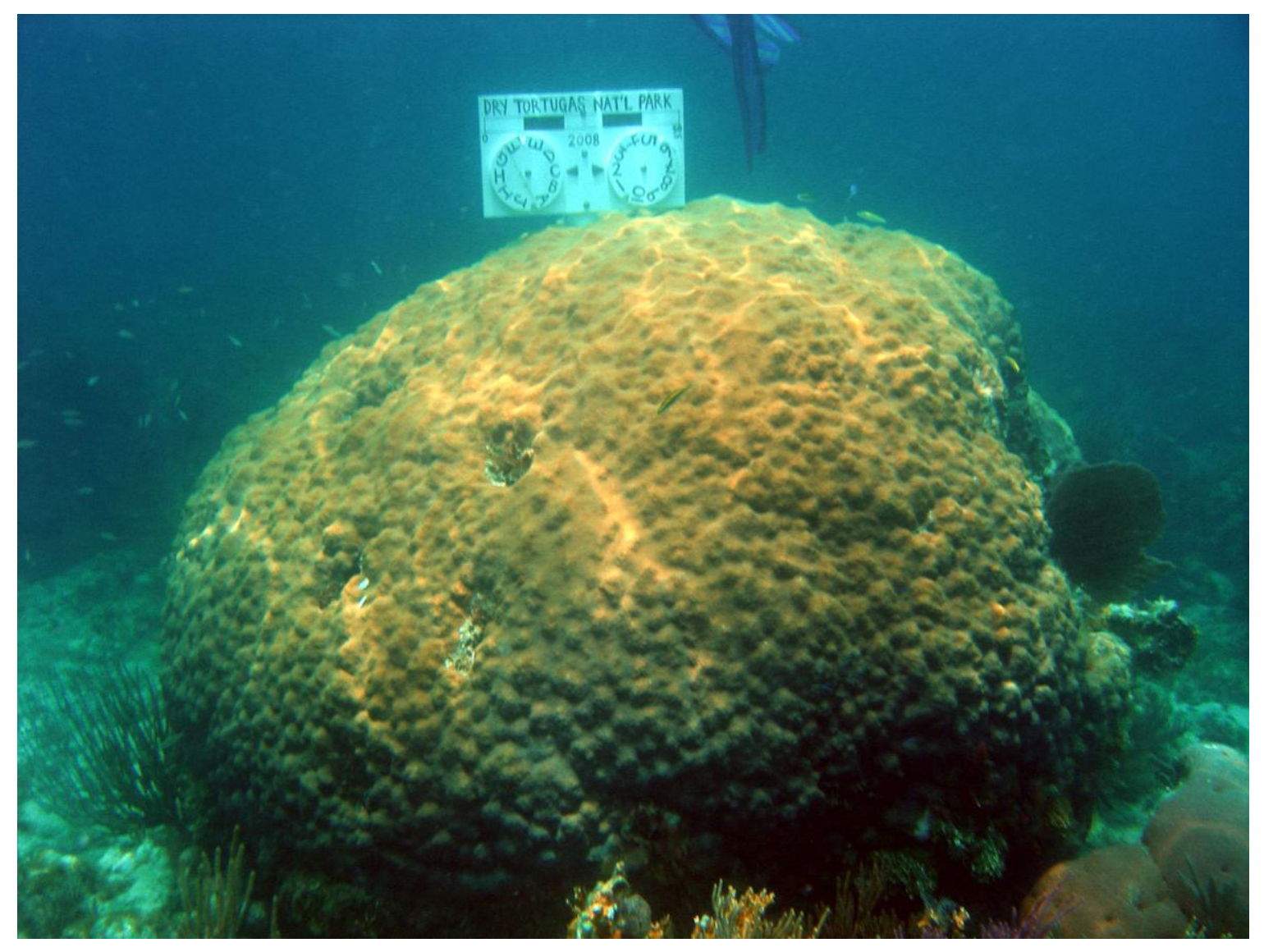

Site 08PS-C2, Montastraea faveolata. 
Appendix 2. Lithologic logs and core photographs, Dry Tortugas National Park, Florida 
Classification of Carbonate Rocks According to Depositional Texture (after Dunham, 1962)

\begin{tabular}{|c|c|c|c|c|c|}
\hline \multicolumn{5}{|c|}{ DEPOSITIONAL TEXTURE RECOGNIZABLE } & \multirow{4}{*}{$\begin{array}{l}\text { DEPOSITIONAL TEXTURE } \\
\text { NOT RECOGNIZABLE } \\
\text { Crystalline Carbonate }\end{array}$} \\
\hline \multicolumn{4}{|c|}{ Original Components not Bound Together During Deposition } & \multirow{5}{*}{$\begin{array}{c}\text { Original components } \\
\text { were bound together } \\
\text { during deposition... } \\
\text { as shown by intergrown } \\
\text { skeletal matter, } \\
\text { lamination contrary to gravity } \\
\text { or sediment-floored cavities that } \\
\text { are roofed over by organic matter and } \\
\text { are too large to be interstices. } \\
\text { Boundstone }\end{array}$} & \\
\hline (partic & $\begin{array}{c}\text { Contains mud } \\
\text { les of clay and fine }\end{array}$ & silt size) & Lacks mud & & \\
\hline \multicolumn{2}{|c|}{ Mud-supported } & \multirow{2}{*}{ Grain-supported } & \multirow{2}{*}{$\begin{array}{c}\text { and IS } \\
\text { grain-supported }\end{array}$} & & \\
\hline $\begin{array}{c}\text { Less than } \\
10 \text { percent grains }\end{array}$ & $\begin{array}{c}\text { More than } \\
10 \text { percent grains }\end{array}$ & & & & \multirow[t]{2}{*}{$\begin{array}{l}\text { (Subdivide according to } \\
\text { classifications designed to bear } \\
\text { on physical texture or diagenesis.) }\end{array}$} \\
\hline Mudstone & Wackestone & Packstone & Grainstone & & \\
\hline
\end{tabular}

Patterns Used in Well Logs and Their Corresponding Lithologies
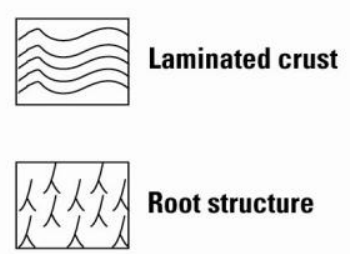

Root structure

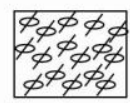

Soilstone clasts

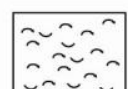

Skeletal debris

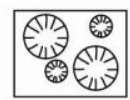

Head corals

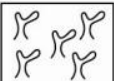

Branching corals

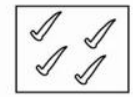

Echinoids

$$
\begin{array}{|cc}
\# \# & \# \\
\# & \# \\
\# & \#
\end{array}
$$

Bryozoa (Schizoporella)

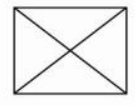

No recovery

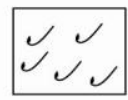

Oyster
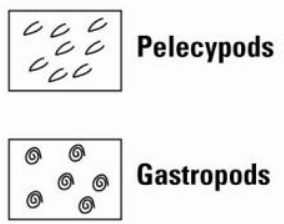

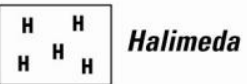
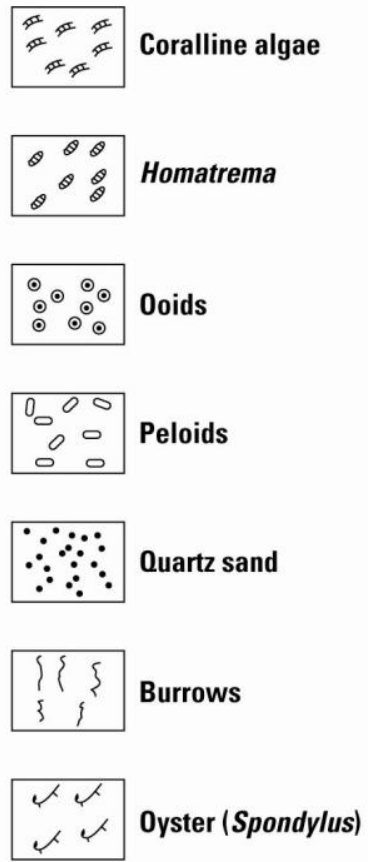

ॠ व

Core log descriptions 


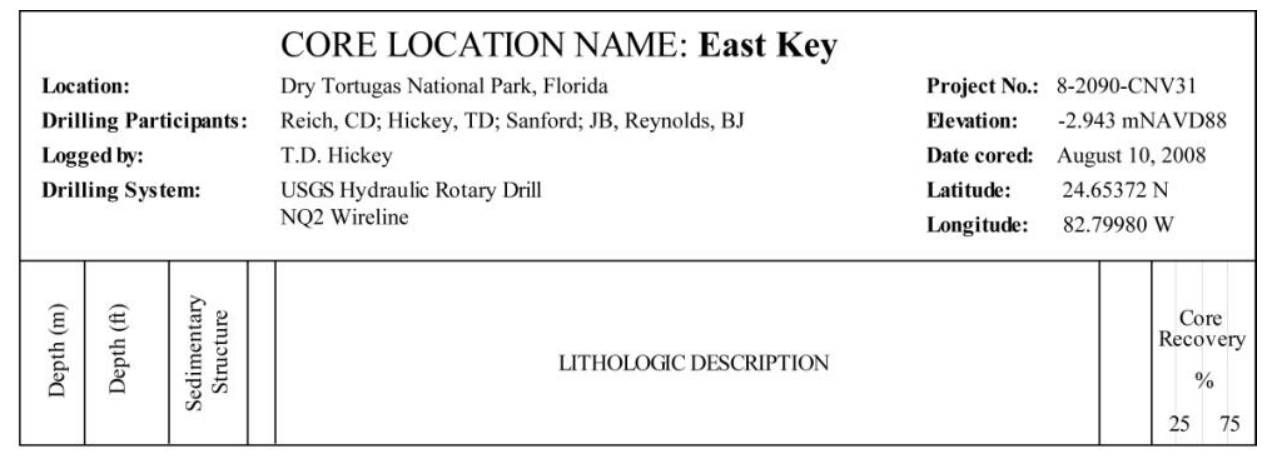

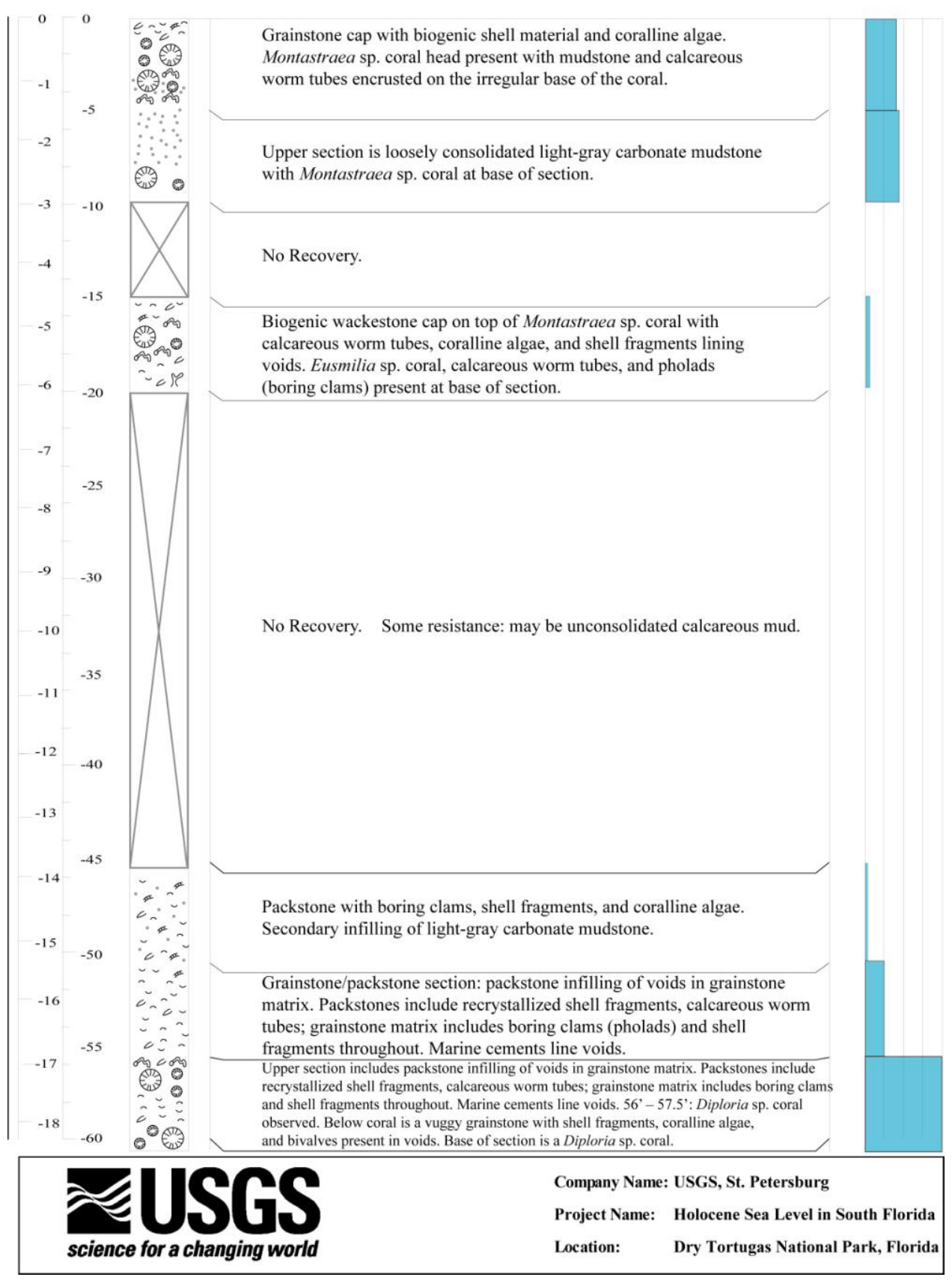

Core log for East Key 


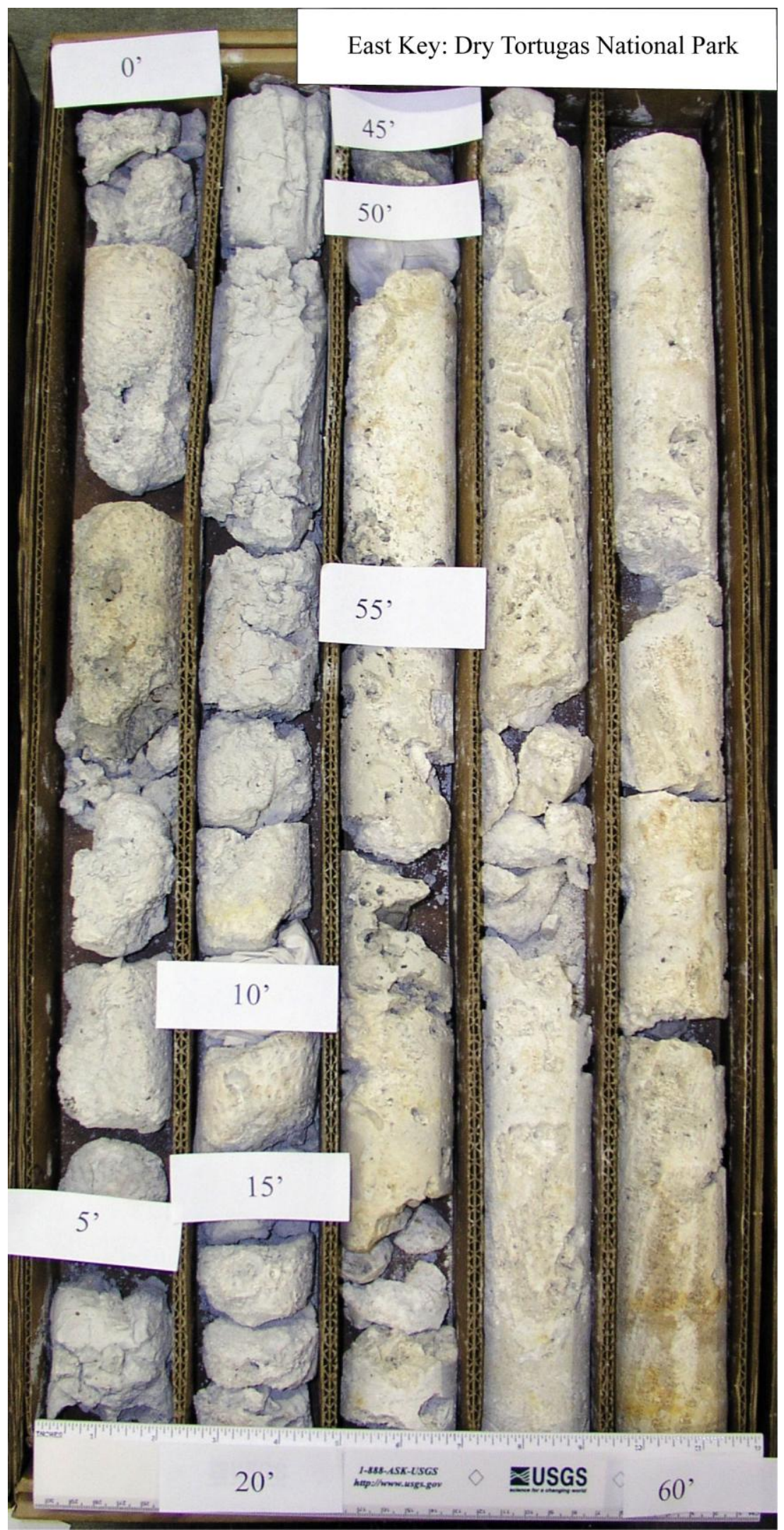

East Key core. 


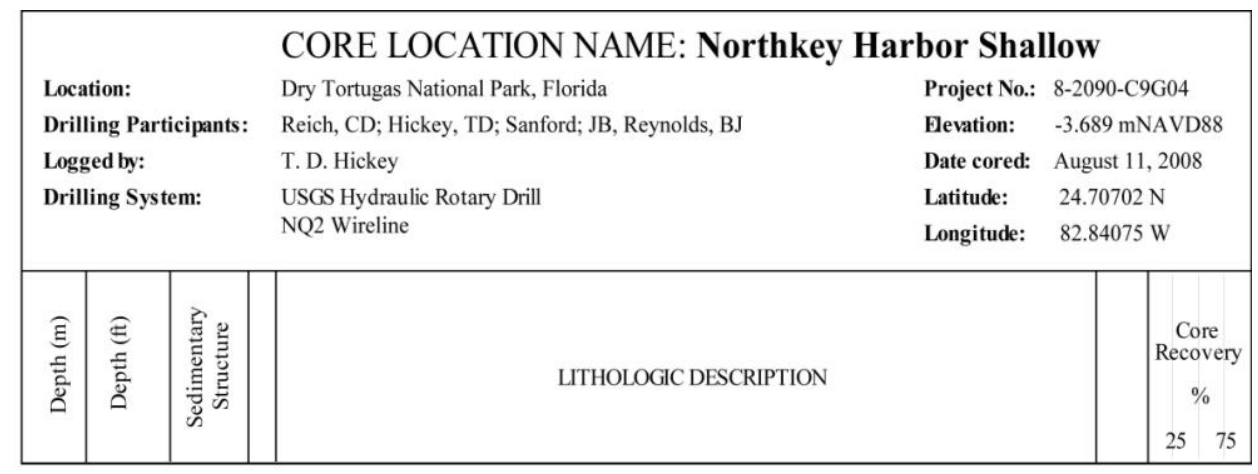

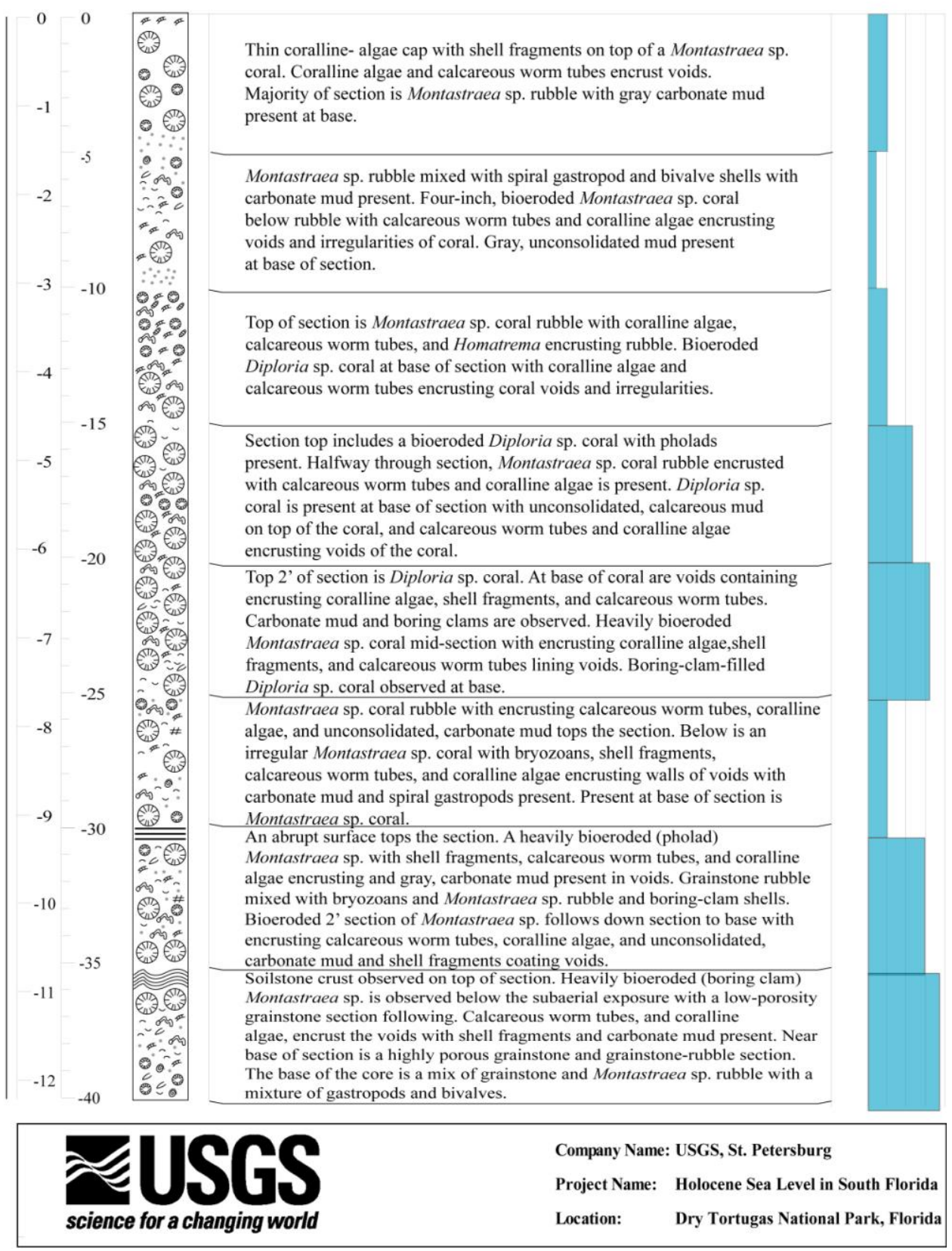

Core log for Northkey Harbor Shallow. 


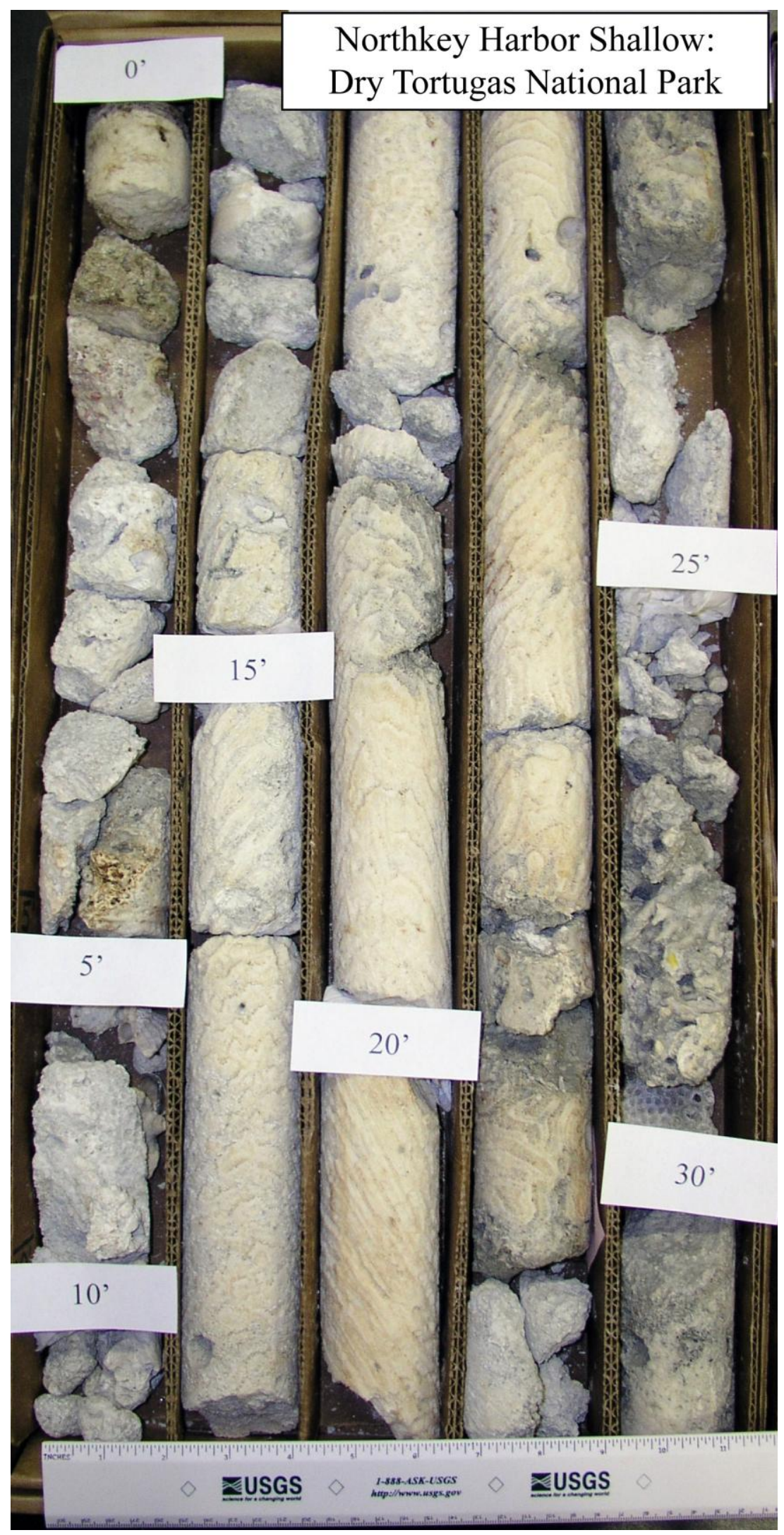

Northkey Harbor Shallow core, box 1 of 2. 


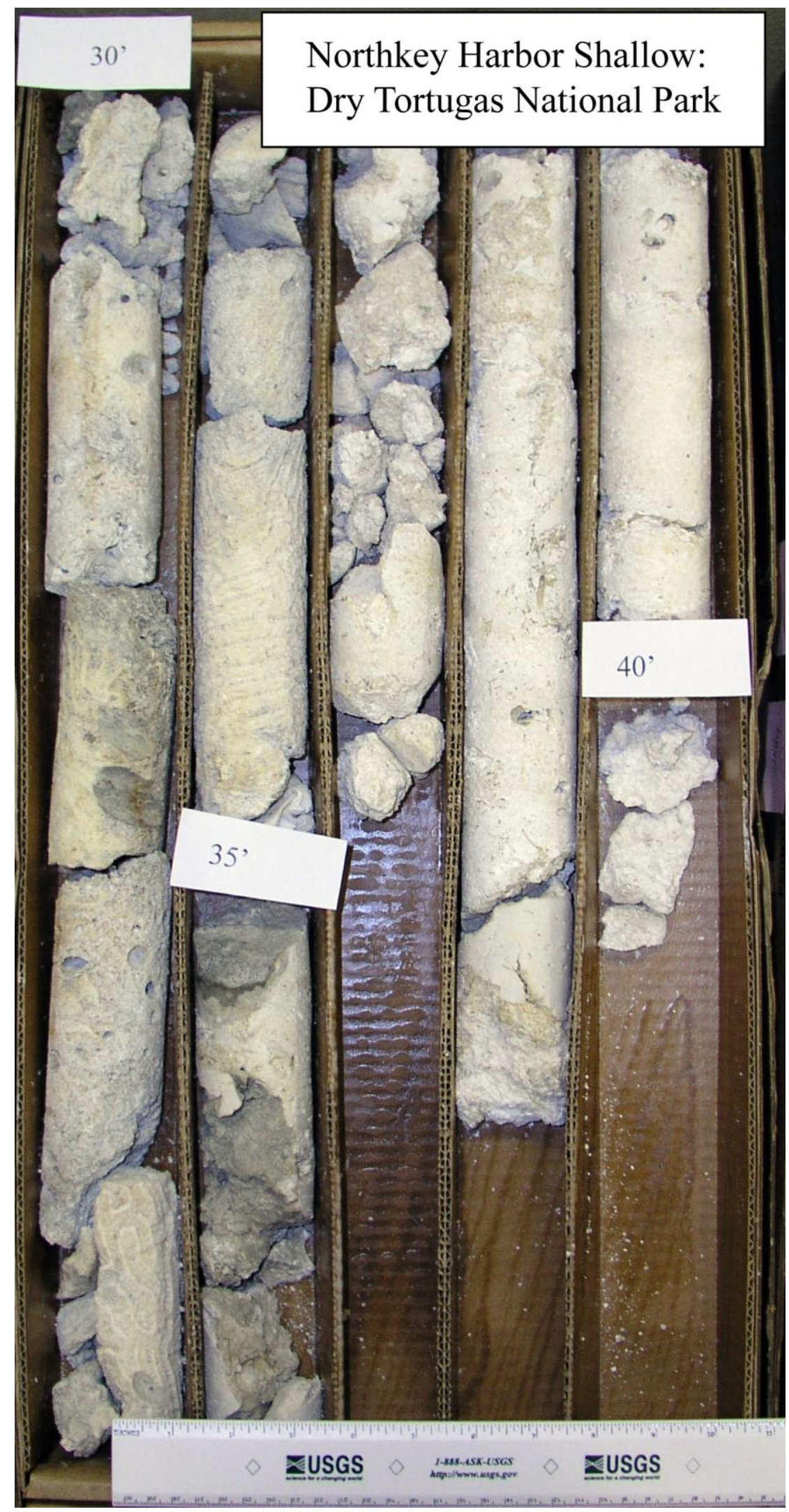

Northkey Harbor Shallow core, box 2 of 2. 


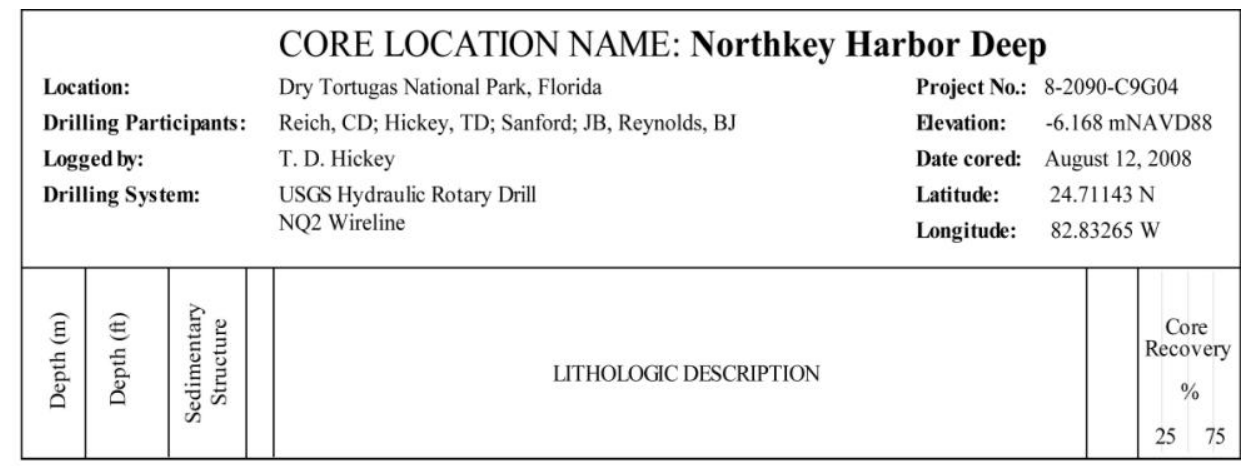

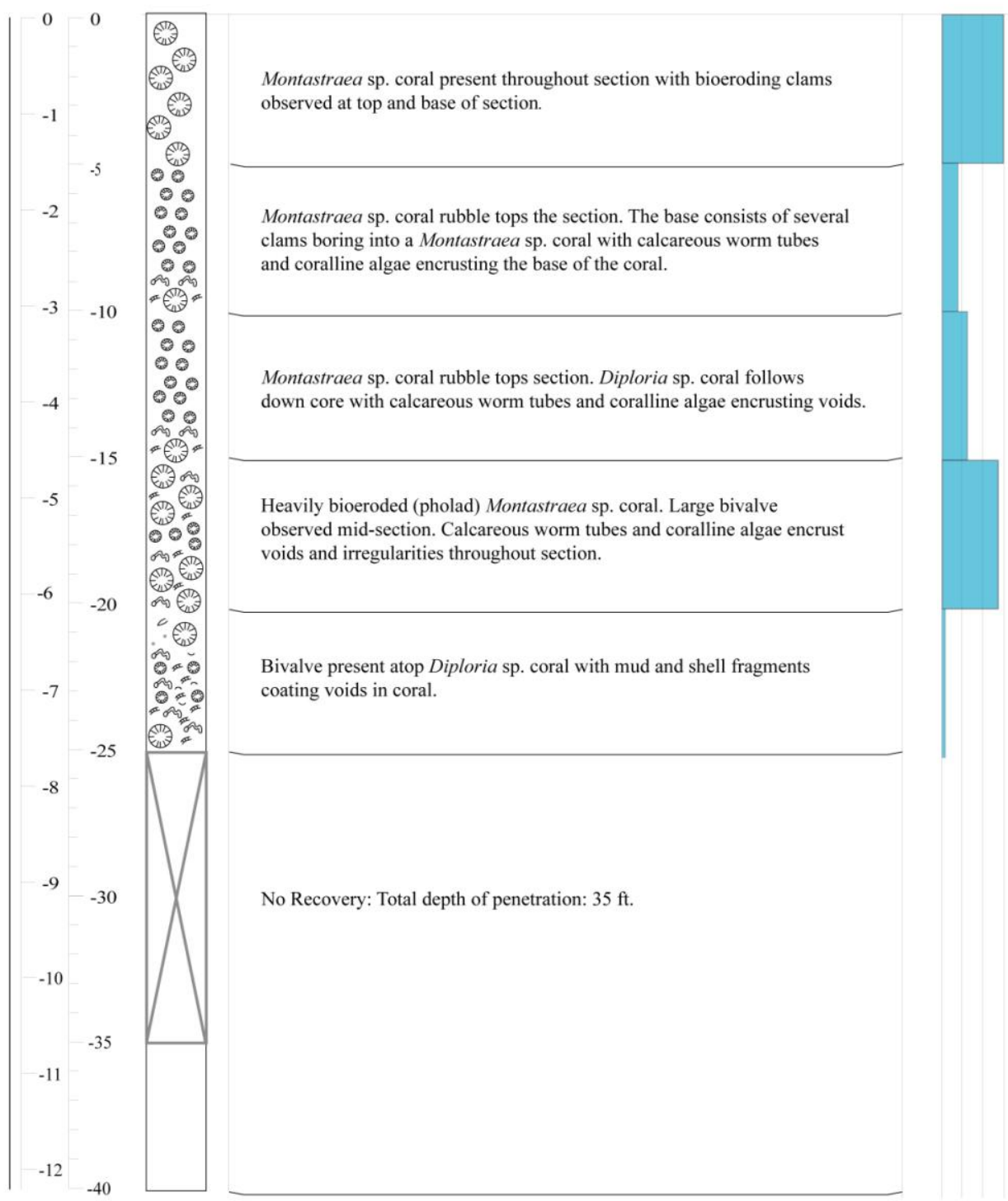

$\begin{array}{ll}\text { science for a changing world } & \begin{array}{l}\text { Company Name: USGS, St. Petersburg } \\ \text { Project Name: } \\ \text { Location: }\end{array} \\ \text { Dry Tocene Sea Level in South Florida } \\ \text { Das National Park, Florida }\end{array}$

Core $\log$ for Northkey Harbor Deep. 


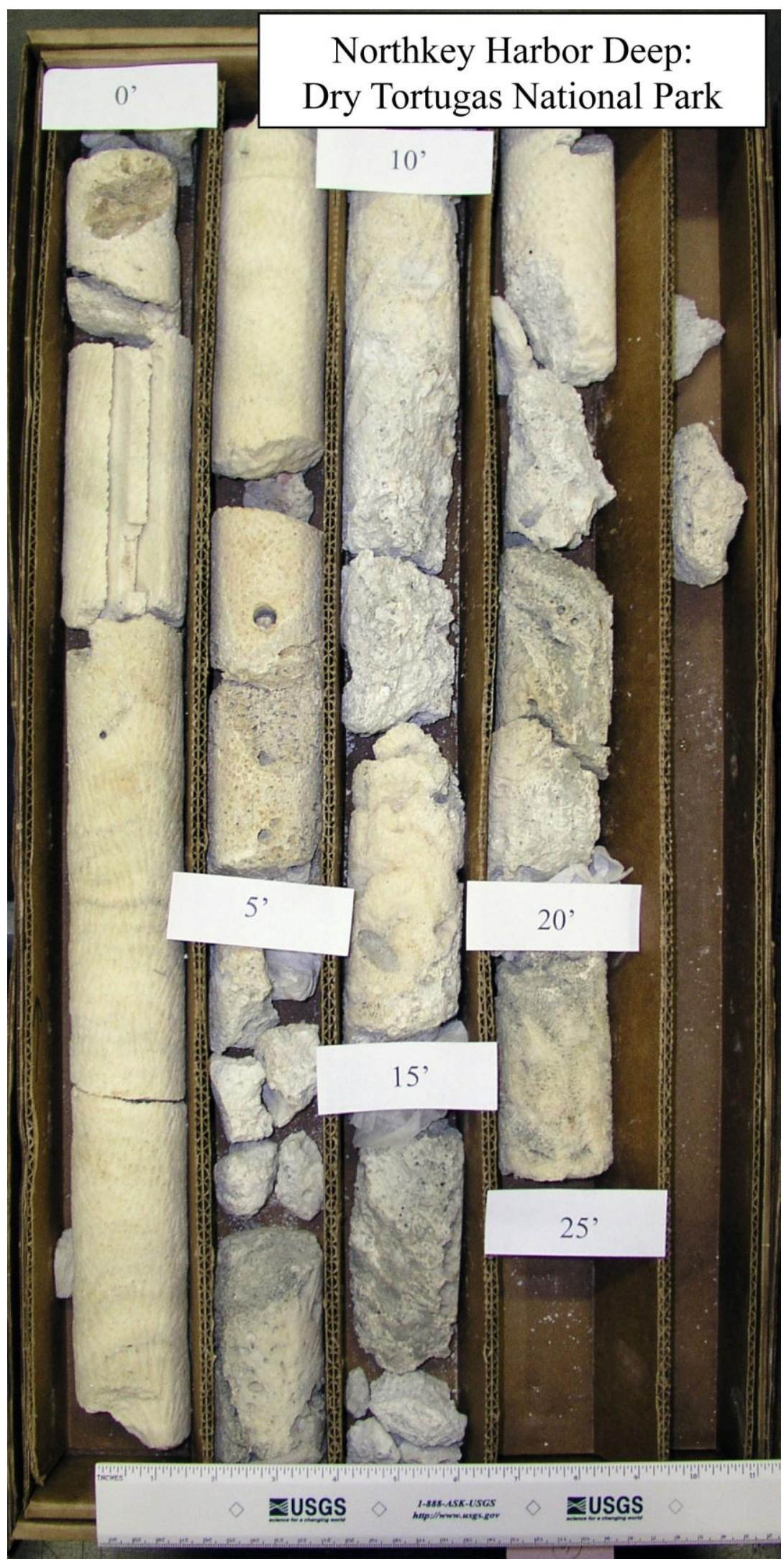

Northkey Harbor Deep core. 